\title{
The Influence of Newer Member States in the European Union: The Case of Poland and the Eastern Partnership
}

NATHANIEL COPSEY

KAROLINA POMORSKA

Abstract

This article seeks to examine and assess the role of Poland in the early stage making of the Eastern Partnership (EaP) of the European Union (EU). First, it briefly reviews Poland's aims and ambitions with regard to the European Union's policy towards its eastern neighbours, both before and since it joined the European Union in 2004. Second, it describes and analyses the EaP, including its added value for the European Neighbourhood Policy (ENP). Third, it draws on a range of interviews carried out by the authors in Brussels and Warsaw on Poland's role in the initial formation of the EaP, as seen by its partners in the other Member States and European institutions. In addition, it seeks to unpack some of the early stage lessons learnt by the Polish government about how best to achieve its ambitions in the EU, and notes the remaining weaknesses of the Polish administration, particularly in the area of administrative capacity.

THIS ARTICLE SEEKS TO EXAMINE AND ASSESS THE ROLE OF POLAND during the initial establishment phase of the Eastern Partnership (EaP) of the European Union (EU), as viewed by key EU and Polish political elites. The EaP was jointly launched by Poland and Sweden in 2008 as a means of reinforcing the eastern dimension of the European Neighbourhood Policy (ENP). The article contributes primarily to the growing body of scholarship on the impact and influence of newer Member States of the European Union as unlikely power brokers on its policy agenda (see, for example, Dangerfield 2010). The article also contributes to the study of the EU's role in its eastern neighbourhood and provides new empirical evidence on the formulation and negotiation of the EaP (Dannreuther 2004; Emerson 2004; Emerson et al. 2007; Kelley 2006; Schimmelfennig \& Scholz 2008; Smith 2005; Weber et al. 40 2007; Bechev \& Nicolaidis 2010; Whitman and Wolff 2010a). The original interview material on which this article is based was largely gathered between 2007 and 2010, and as such deals with the stage leading up to the creation of the Eastern Partnership in 2008 and its initial period of functioning. Subsequent developments are not considered.

This article draws upon the authors' earlier work (Copsey \& Pomorska 2010) that established a framework for evaluating the capacity of Member States to exercise Lukes' (2005) second dimension of 'power', or rather 'influence', in the European 
Union, which was then applied to Poland as a case study. ${ }^{1}$ The article returns to the question of how power and influence is exercised in the EU by the Member States in the conclusion. Our previous article argued that Poland's influence in the first few years of EU membership had been low. This earlier study concentrated on the domestic sources of Polish European policy, and looked mainly, although not exclusively, at Poland's efforts in the European Union through the eyes of civil servants, politicians, private sector analysts and various lobbyists based in Warsaw. The focus of this article is on what might be termed a 'peer review' of Polish performance within the European Union, and specifically in the field of its eastern policy. To achieve this, the article draws principally on a series of 55 interviews conducted by the authors in Brussels and Warsaw with diplomats from the Permanent Representations of 10 Member States, as well as with officials from the European 60 Commission, the Council Secretariat General, Members of the European Parliament (MEPs) and a selection of independent policy analysts. ${ }^{2}$

The article is primarily empirical in its approach, but it also builds on the framework put forward in the authors' earlier article (Copsey \& Pomorska 2010) for assessing the influence of Member States on a given policy domain. The capacity of individual Member States to exercise influence within the EU on the making of a particular policy remains a much under-researched area of academic enquiry even though it is an issue of profound importance (see Bulmer \& Lequesne 2002). Scholars have tended to shy away from this question because it is extremely hard to 'measure' or evaluate power or influence. In terms of previous attempts to investigate this matter, there is the grand theory of Liberal Intergovernmentalism put forward by Moravcsik (1998), as well as the work of Tallberg (2008), Wallace et al. (2005) and our own modest contribution to this area of enquiry (Copsey \& Pomorska 2010). However, all of these theories share the age-old social scientist's dilemma of establishing causality between a given action and a particular outcome. Moreover, published literature on the policy preferences of the 12 post-2004 Member States, let alone their capacity or desire to upload these items onto the European Union agenda has been somewhat limited, particularly with regard to the first years of membership. This was due to firstly the relatively short period of time that has elapsed between their accession and the time when our interviews ended in 2010, (see Copsey \& 80 Haughton 2009) and secondly, to the fact that many of the smaller newer Member States (and the majority are rather small) have expressed no explicit desire to be influential in the Union. Poland is an important exception to this (Copsey \& Pomorska 2010) and has made its wish to be a policy-maker as well as a policy-taker explicit, which is why our study focuses on this state.

85 The difficulties and complexities that are inherent in researching the influence of individual Member States on the European policy agenda are no excuse for avoiding the question altogether. Rather we argue that scholars should proceed with small steps towards the aim of developing a sounder theoretical base for assessing the influence of Member States. Empirical studies such as this article should help guide future 90 theorists. In this article we focus on perceptions of the influence of Poland on the EU

\footnotetext{
${ }^{1}$ Lukes' second dimension of power is the ability to exercise influence, persuasion and coercion to secure a particular outcome, where there is a conflict of subjective interests (Lukes 2005, pp. 20-25).

${ }^{2}$ Fifty-five semi-structured interviews were conducted during the project between 2007 and 2010 in Warsaw and Brussels and the data was subsequently transcribed and coded. Interview transcripts have been anonymised to protect the identity of the interviewees. In this article, each interview has been numbered by the authors, giving the date and place of the interview. A full list of interviews was disclosed to the editors and peer-reviewers.
} 
agenda (what Europeanisation scholars call 'uploading'). The perceptions are those of the officials involved in the policy-making process, predominantly based in the European Commission's DG-RELEX or Permanent Representations of the Member States to the EU. The authors freely acknowledge that influence and perceived influence are not the same thing, but would reiterate that if a Member State wishes to be influential in the European Union, a necessary, though not sufficient, condition is that it needs the good opinion of its peers. Consequently the perceptions of both officials from other Member States and officials from the EU institutions are of great importance.

100 The structure of the article is as follows. Section One briefly reviews Poland's aims and ambitions with regard to the European Union's policy towards its eastern neighbours, both before and during the first years of its membership after 2004 . Section Two describes and analyses the Eastern Partnership and its added value for the European Union's Neighbourhood Policy. Section Three draws on the interviews carried out by the authors in Brussels and Warsaw in order to evaluate Poland's ability to adapt quickly to the role of policy maker during the first 6 years of its membership and influence the making of the Eastern Partnership, as seen by other Member States and officials from the European institutions. In addition, the final section of the article unpacks the lessons learnt by the Polish government in the early years of its EU membership about how best to achieve its ambitions in the EU, and notes certain weaknesses of the Polish administration, particularly in the area of administrative capacity.

Relations with its Eastern neighbours were among the great challenges for modern Polish foreign policy, as formulated from 1990. Consequently, they became one of the top priorities for Polish diplomacy within the EU. Poland's initial post-1989 policy choices were made in accordance with a series of concepts formulated in the 1960s by Juliusz Mieroszewski and Jerzy Giedroyc, both of whom advocated support for an independent Ukraine, and which were originally set out in the Paris-based émigré journal, Kultura. In 1989, the Polish political elite soon recognized that better relations with the Eastern neighbours could mean gaining a stronger position within Western Europe (Kupiecki \& Szczepanik 1995, p. 75). After the initial 'dual-track'

125 policy, designed as an attempt to maintain a balance between Moscow and the newly independent post-Soviet states, a new and more active policy approach was formulated in 1994 (Olechowski 1994). Its aim was to build good relations with the states of special significance for Poland: Russia, Ukraine, Belarus, the Baltic States, Kazakhstan and Moldova. Relations with Ukraine were characterized as a strategic 130 partnership of crucial importance, which was later to be reflected in the role of Poland as an advocate for Ukraine's closer ties with the EU (Buras \& Pomorska 2006).

Prior to the 2004 accession, the Polish government had already begun to lobby in favour of creating an independent 'Eastern Dimension' to EU relations with the countries to its east. In 2003, the Polish Ministry of Foreign Affairs (MFA) released a 135 non-paper ${ }^{3}$ that outlined the main aims of the proposed policy (MFA 2003). The first objective was to enable East European partners, such as Ukraine and Moldova (but potentially also Belarus), to join the EU when they were willing to and when they

\footnotetext{
${ }^{3}$ A non-paper (a term very commonly used in Brussels and in diplomatic jargon in general) is a document that is usually circulated informally between the Member States.
} 
were ready and able to fulfil the membership criteria. Polish officials stressed that 'Europe does not end at the EU's Eastern borders, nor will it end there after enlargement' (Cimoszewicz 2004) and did not hesitate to admit that 'Poland is a strong advocate of the European aspirations expressed repeatedly by Ukraine and Moldova' (Cimoszewicz 2004). This strategic goal essentially remained unchanged and represented the underlying long-term constant for Polish initiatives regarding the ENP. What did change was Poland's approach, which shifted to recognise the need 145 for incremental steps to promoting its policy preferences for the eastern neighbourhood. This was important because Poland's promotion of Ukraine did not strike a chord with all EU Member States or institutions with some continuing to view the broad focus ENP as the primary means of engagement with Ukraine (Longhurst \& Zaborowski 2007, p. 85). In this respect, it appeared that Poland had failed to initially 150 upload the idea of a specific Eastern dimension to the EU's ENP. The 2003 Polish non-paper, as admitted later by some Polish diplomats ${ }^{4}$ was not deemed pragmatic enough, because the Poles lacked valuable inside knowledge on how the EU functioned.

There were identifiable differences between the emergent broad-based, inclusive ENP (which included the EU's southern neighbours as well as its eastern ones) supported by old Member States such France and the Polish position on how the EU's relations with the East should be structured. However, even though officials in the Polish MFA admitted that the ENP was 'far from the ideal that was presented [by the UK] in 2002', the EU's attempt to develop a 'circle of friends', including those on its

160 Eastern borders was, in principle, welcomed by Warsaw. Poland also quickly recognised that adopting a pragmatic, 'small-steps' approach, would allow it to continue to push for incremental changes to the existing EU neighbourhood policy. At the same time, Poland continued to promote the issue of membership for Ukraine and other eastern neighbours, thus keeping it high on the ENP agenda. As one MFA 165 official put it, the perspective of membership 'worked in our case and is working for the Balkans', therefore by implication, it should also work for the states beyond Poland's and the EU's eastern border. ${ }^{6}$ Minister of Foreign Affairs Stefan Meller referred to these states when he gave his annual address to the Polish parliament (Sejm) in January 2006:

We will seek to ensure that the emerging Eastern Dimension of the Union's Neighbourhood Policy draws the countries involved closer to the Union. At the same time, they should not be doomed to the role of "eternal partners". At least some of them - the ones with a pro-European orientation and advanced internal transformations - should be given the prospect of membership, however distant it may be. (Meller 2006)

In 2006, Polish Foreign Ministry diplomats presented a 'food for thought' document to the European Council (MFA 2006). The document submitted in parallel to separate proposals from the German and Lithuanian governments, talked of both 180 the 'Eastern Dimension' and future relations with Ukraine. It advocated acknowledging the strategic importance of EU-Ukraine relations, as well as the need for the swift conclusion of visa facilitation and readmission agreements, and the necessity to strengthen EU efforts to resolve frozen conflicts in the South Caucasus and Transnistria.

\footnotetext{
${ }^{4}$ Interview 46, Polish Ministry of Foreign Affairs, Warsaw, 10 May 2005; Interview 23, UK Embassy, Warsaw, 20 October 2005.

${ }^{5}$ Interview 46, Polish Ministry of Foreign Affairs, Warsaw, 10 May 2005.

${ }^{6}$ Interview 46, Polish Ministry of Foreign Affairs, Warsaw, 10 May 2005.
} 
The opportunity to create an independent framework for policy towards the East came back onto the agenda in 2007. At this time another, albeit brief, Polish nonpaper was circulated. Unlike previous Polish initiatives, this document avoided direct reference to the Eastern Dimension. Rather, it emphasized the development of 'regional cooperation' in the context of the new independent eastern framework as something complementary to the existing policies, such as the ENP, the Northern Dimension and the Euro-Mediterranean Partnership (EURO-MED). The six countries to which the framework would apply included Ukraine, Moldova, Armenia, Azerbaijan, Georgia and potentially also Belarus, all of which were later included in the EaP. The Polish suggestion was followed by a similar document from the Czech 195 Republic. The ideas were also discussed by the four Visegrád states (Cianciara 2008). However, as reported by one of the interviewees, ${ }^{7}$ discord between the partners prevented the initiative being 'branded' as a Visegrád proposal. Whether Poland would have benefited from presenting the $\mathrm{EaP}$ as a joint Visegrád initiative is doubtful. Certainly a proposal from a larger group of newer Member States may well 200 have initially gained a more favourable reception from within the Commission. ${ }^{8}$ However, as stated, the political discord at the working level within the Visegrád group at this time prevented the Visegrád partners adopting Poland's proposals as shared policy and there was no real incentive for Poland to push the policy within the Visegrád group because the V4 partners would be likely to support any policy move 205 to improve relations with the eastern neighbours wherever it came from. Poland therefore appeared to have the opportunity to advance its position as an independent actor within the EU outside the confines of the Visegrád sub-regional partnership.

The next Polish move was at the high political level. The Polish Minister of Foreign Affairs, Radek Sikorski, managed to convince his Swedish counterpart to 210 support the idea of an Eastern Partnership as a distinct dimension of the wider ENP. Considering that Sweden was about to take over the rotating presidency of the EU, the choice of partner was an astute move on the part of Poland. It essentially allowed the idea to be marketed as a joint initiative between a respected incumbent Member State and a new member. The Polish-Swedish non-paper on Eastern Partnership was 215 presented on the 26 May 2008 to the Council of the European Union's General Affairs and External Relations Council (GAERC) meeting in Brussels. The paper had been prepared by the Polish MFA, in consultation with the Polish Permanent Representation to the EU in Brussels. ${ }^{9}$ Think-tanks in Warsaw were also engaged in the conceptual phase, especially the Institute for Eastern Studies (Ośrodek Studiów 220 Wschodnich, or OSW). The draft proposal built on previously presented documents and introduced the new idea of multi-lateral co-operation in the region and differentiation between the partners.

The 'Conclusions of the European Council' in June 2008 welcomed the PolishSwedish proposals on the establishment of the EaP and asked the Commission to 225 work on a more detailed programme (Council of the EU 2008, p. 19). Despite this positive development, these conclusions were much more modest than Poland initially wished for and proved to be more general when compared to the detailed text on the Union for the Mediterranean (UMed) which was also to be found in the Council's official conclusions. While some (Commission) officials saw this as the result of a

\footnotetext{
${ }^{7}$ Interview 54, European Commission DG External Relations, Brussels, 23 November 2009.

${ }^{8}$ Interview 41, European Commission DG External Relations, Brussels, 11 December 2009.

9 'Polish-Swedish Proposal: Eastern Partnership', June 2008, available at: http://www.msz.gov.pl/Polish-Swedish,Proposal,19911.html. The draft version of the proposal presented to the European Council was dated 23 May 2008.
} 
230 lack of ambition on the part of Poland, compared with that presented and argued for by France on the UMed, other officials from the Council's Secretariat General claimed it was a sign that Poland had learned to compromise and to better co-ordinate its policy goals with those of other Member States. ${ }^{10}$ These two opposing views show that the exact influence of Poland in the creation of the EaP and its content was

235 unclear to some officials at this early stage. There appeared to be a degree of ambiguity on the part of officials about Poland's role in the making of the EaP, raising questions about the real degree of influence over the development of the EaP Poland had at this time. It is this ambiguity that this article seeks to address through a detailed analysis of a set of elite interviews on the matter. Before turning to this, however, it is 240 essential to describe and analyse what the Eastern Partnership was deemed to be and what it added to the EU's policy toolkit in the eastern neighbourhood.

\section{Origins of the Eastern Partnership}

245 The importance of the EU's policy towards its neighbours was acknowledged in the 2003 European Security Strategy (ESS), which included references to security in the 'EU neighbourhood' within three of the Union's strategic objectives. It stated that 'neighbours who are engaged in violent conflict, weak states ... organized crime ... dysfunctional societies ... [and] exploding population growth on its borders all pose

250 problems for Europe' (Council of the EU 2003). Regarding the East, it was asserted that it was not in the EU's interest to create new dividing lines as a result of enlargement to central and eastern Europe (CEE) and, therefore, the EU should seek to extend 'the benefits of economic and political cooperation [...] while tackling political problems [in the eastern neighbourhood]' (Council of the EU 2003). Thus the

255 origins of the EaP can be traced back to the years immediately prior to the fifth enlargement of the Union to CEE in 2004/2007 (European Commission 2003, p. 3) which saw the EU recognise the need to take account of its new borders which brought it closer to the relatively more politically unstable and economically less developed former Soviet republics of Ukraine, Belarus and Moldova. Prior to this, the

260 EU's policy in the region was mainly concerned with its relations with its CEE candidate Member States on the one hand, and Russia on the other, with little consideration for other former Soviet republics.

The first move by the EU to respond to the geopolitical and security realities of CEE enlargement came in the form of a proposal made by the UK in 2002, which

265 became known as the New Neighbours' Initiative (NNI) and was initially aimed only at three countries: Ukraine, Belarus and Moldova. A year later, as a consequence of lobbying by the Southern EU states, the programme was extended to include a number of the EU's Southern partners located around the Mediterranean fringe and was renamed as 'Wider Europe'. The concept was further developed by the

270 Commission in a Strategy Paper published in May 2004 (European Commission 2004). This subsequently led to yet another change in the name of the initiative, which from then on became known as the European Neighbourhood Policy. As argued by a senior official of the Commission, the novelty of the ENP was based on its new strategic framework, which was 'an example of our foreign policy being more than 275 traditional diplomacy' (Landaburu 2006, p. 3), in the sense that it combined policies

\footnotetext{
${ }^{10}$ Interview 38, European Council, Brussels, 9 December 2009.
} 
from all traditional 'pillars' of the EU. Such an approach was arguably more comprehensive than conventional foreign policy.

From the outset the ENP was widely perceived as an inadequate mechanism for (1) stabilizing all the EU's neighbours and (2) setting them on a path towards much closer economic and political integration with the European Union, not least because the policy's scope was so broad: covering an arc of states from Morocco in the southwest, through north Africa, the Middle East and the Caucasus to Moldova, Ukraine and Belarus in the north. Moreover, although the ENP did envisage, at least in the very long term, a European Economic Area-style relationship for the ENP countries, at the behest of less enlargement-friendly Member States, such as France and the 'Club Med' countries, the policy deliberately made no mention of the possibility of the eventual accession of any of the ENP partners to the European Union. This lack of a powerful incentive for the ENP states to undertake difficult and expensive economic and political reforms, curtailed the policy's development from the outset (see e.g. 290 Sasse 2010, pp. 181-2). Moreover, the very notion of such a geographically wideranging ENP managed simultaneously to offend the target countries in both North Africa (who were vexed at being grouped with former Soviet republics) and in Eastern Europe (who were angered by being placed on an equal footing with 'nonEuropean' countries that according to Article 49 TEU lacked even the possibility of eventual EU accession).

The question of accession has proven to be particularly important in the debate about the future of the ENP for the eastern European states targeted by the policy. This has challenged official EU rhetoric on the issue and even though the discourse was somewhat softened and no longer referred to partnership as a 'substitute for 300 enlargement', the Commission clearly stated that the EU 'emphasized that it offers [the ENP as] a means to reinforce relations between the EU and partner countries, which is distinct from the possibilities available to European countries under Article 49 of the Treaty on European Union' (European Commission 2004, p. 3). On this vital point the EU's Member States were strongly divided, with many of the newer, 305 northern and eastern Member States more strongly in favour, and the older, particularly southern, Member States far less enthusiastic, and indeed categorically opposed, to any talk of membership for ENP states. Whilst the argument could be made under Article 49 of the 1992 Treaty on European Union (TEU) that the 'European' ENP states of Ukraine, Moldova and Belarus certainly have the theoretical 310 right to apply for EU membership, it is very doubtful that they would come close to qualifying for membership for a considerable period of time. As such, it has been argued that the ENP neither sufficiently confronts 'the ghost of enlargement', nor seriously addresses problems affecting neighbouring states or achieves coherence with relations to them (Smith 2005, p. 767; Emerson, Noutcheva \& Popescu 2007; 315 Whitman \& Wolff 2010b, pp. 12-13).

Nonetheless, it was precisely this difference between the potential future status of the ENP countries in the east from those in the south that encouraged those EU Member States friendly towards eastern Europe (led by Poland) to push for a change in the nature of the relationship between the EU and the eastern ENP countries. 320 Following the 2008 joint proposal by Poland and Sweden to the European Council for the creation of the so-called Eastern Partnership, the European Council finally requested a detailed proposal from the Commission, which was originally scheduled 
to be unveiled during the Czech Presidency of the European Union during the first half of $2009 .^{11}$

325 This small, but important step for the development of the EaP was, however, soon to take on a more hurried pace with the EaP dramatically rising in importance on the European foreign policy agenda following Russia's intervention in the conflict between Georgia and its breakaway regions of South Ossetia and Abkhazia in August 2008. This was the first time that Russian forces had intervened militarily outside of the Russian Federation in the ex-Soviet space since 1991. The rapid disintegration of the Georgian army and the speed of the Russian advance beyond the territories of South Ossetia and Abkhazia towards Tbilisi prompted an emergency meeting of the European Council to discuss the situation. The feeling that the Union urgently needed to act decisively and demonstrate a plausible commitment to stabilizing what, in

335 August 2008, appeared to be a highly volatile region, led to the decision to bring forward the launch of the Eastern Partnership to 3 December 2008 (European Commission 2008, 823 final). The resultant Commission document was endorsed by the 27 Foreign Ministers of the EU and 5 Eastern Partnership (Armenia, Azerbaijan, Georgia, Ukraine and Moldova) states in a Joint Declaration following the Prague Eastern Partnership Summit on 7 May 2009 (European Council 2009).

\section{Content of the Eastern Partnership}

The EU's external relations with its near neighbours is a policy area that was already well furnished with initiatives, but the addition of the EaP certainly strengthened the EU's toolkit with regard to Eastern Europe. The EaP's rhetoric was based on what the Commission called 'a lasting message of EU solidarity' (European Commission 2008) between the EU and the 'European' ENP states; but, far more importantly, it also sought to provide new tools to assist with the pre-existing and longer-standing ENP

350 objectives of nurturing democracy, the rule of law and the development of free market economies through an open-ended European integration process, albeit one that would not necessarily lead to full accession. Its second area of novelty lay in encouraging the EaP countries to cooperate multi-laterally between themselves, under the watchful eye of the European Union; this would provide the motor for the regional cooperation 355 deemed so important for their future security. In addition to the established ENP goal of a European Economic Area (EEA)-style integration between the EU and the ENP countries, the EaP foresaw the creation of a regional 'Deep and Comprehensive Free Trade Area' between the EaP countries as a precursor to deeper economic integration with the EU - performing a similar function to that of the Central European Free

360 Trade Association (CEFTA) for the central European states in the 1990s. However, in common with the CEFTA countries in the 1990s, enthusiasm for the idea was somewhat muted - after all what mattered to the EaP countries was access to the wealthy single market. For the EU, however, encouraging the EaP countries to work together was of paramount importance.

365 The EaP retained the pre-existing bi-lateral elements of cooperation between the European Union and eastern Europe, including the upgrading of relations with the EaP countries, which is envisaged to take place through the signing of a series of Association Agreements. ${ }^{12}$ Considerable mention was also made of the eventual visa

\footnotetext{
${ }^{11}$ Interview 41, European Commission DG External Relations, Brussels, 11 December 2009.

${ }^{12}$ The use of the term Association Agreements was at first contested, with some Member States calling for the name 'Enhanced Agreement' to be employed, implicitly avoiding making a link between the
} 
liberalization necessary to improve the mobility of citizens between the EU and ENP states - but this was expressed more as a longer-term aspiration than as something to be offered immediately. Enhanced cooperation between the EaP countries and the EU was also proposed in a range of policy areas that envisaged eventual convergence in areas ranging from Justice and Home Affairs to education policy. The Association Agreements which were to be negotiated, agreed and ratified on a bilateral basis have proven slow to materialise, with none of the EaP states having as of June 2013 signed an agreement. The agreements are to be governed by Association Councils with the power to make decisions that are legally binding on both parties (the EU and the EaP states), which would, in a small way, redress the vast imbalance in the power relationship between the EU and its eastern neighbours. Separate from the Association

380 Agreements, it was also confirmed that the EaP would include, from the beginning, high-level regular meetings between the two sides. These twice-yearly summits of Heads of State and Government from the EU and the EaP would continue to provide momentum for the integration process and encourage EaP states to keep moving towards the Association Agreements. These meetings would be supplemented by an annual meeting of foreign ministers and a twice-yearly meetings of senior officials. These meetings are considered very useful for the smaller EaP countries which otherwise would struggle to arrange high-level meetings with EU leaders.

Although the bi-lateral agenda of the Eastern Partnership was theoretically attractive to the EaP states (barring the low levels of funding available for the policy 390 where around $€ 785$ million was earmarked for all the EaP countries between 2009 and 2013, compared with the $€ 67$ billion received by Poland alone in structural and regional funds between 2007 and $2013^{13}$ ), it did not really represent much in the way of new goals and objectives. The true policy innovation lay in the development of multi-lateral cooperation, lying on top of the bi-lateral context of the ENP (for more 395 on this last aspect, see Boonstra \& Shapovalova 2010).

\section{Added-Value of the Eastern Partnership}

The launch of the EaP aimed to send a clear message of solidarity to the eastern 400 neighbourhood countries and offered the genuine possibility of much stronger links between them and the European Union through a 'deep and comprehensive free trade area' (DCFTA) and eventual visa liberalization - both of which are highly attractive to the EaP countries. However, these positive elements should be tempered by the fact that the DCFTAs proved difficult to negotiate and there remained a need for these 405 states to prove that they have overcome certain domestic political challenges. For the rest of the EaP states, other than Ukraine, finalisation is likely to take longer, while for Ukraine, its DCFTA agreement was initialled in June 2012, but the subsequent signature and ratification was delayed by the EU following concerns about the rule of law in Ukraine. Visa liberalization also remains an 'aspiration', but with the EU 410 imposing a very strict set of benchmarks and conditionality criteria it is likely that it

\footnotetext{
signing of an Association Agreement and a commitment to eventual accession in the way that followed the signing of the 1994/1995 Association Agreements (also commonly called Europe Agreements) with the central European countries that joined in the Fifth Enlargement in 2004/2007.

13 'Cohesion policy 2007-13: Poland, the biggest beneficiary, has plan and priorities agreed with the Commission'. Commission Press Release, Reference: IP/07/633, Date: 8 May 2007, available at: http://europa.eu/rapid/pressReleasesAction.do?reference=IP/07/633\&format=HTML\&aged=0\&langua ge $=$ EN\&guiLanguage $=$ en, last accessed 5 July 2013 .
} 
will be sometime before visa-free travel between the EU and EaP states is achieved. Another criticism is that the EaP has never guaranteed eventual accession to the Union, nor has it categorically ruled it out, thus allowing the issue to become something of 'an the elephant in the room', although to be fair to the EU, there was no point discussing membership if the definitive answer was to be 'no' for the foreseeable future. This raises very specific questions about the added value of the $\mathrm{EaP}$ and whether it has truly moved the issue of EU-Eastern European relations forwards.

In response to this concern, and looking beyond the high politics aspirations of EU membership, it is possible to observe that the added-value of the EaP may lie primarily in the fact that the policy set in motion the development of the Comprehensive Institution Building (CIB) programme. This was designed to help the $\mathrm{EaP}$ countries prepare for European integration by strengthening their administrative capacity. The CIB sets modest, achievable targets that should, in theory, lead to 425 progress in meeting the policy's stated highline aims and objectives, such as approximating and successfully implementing key elements of the acquis communautaire. This process is monitored annually by the Commission - as was the case with CEE enlargement during the 1990s and early 2000s. This depoliticization of the approach towards the eastern neighbours may prove exceptionally valuable in the 430 future. This is relevant because the ENP was criticized because of its failure to adequately separate 'high' from 'low' politics or technical issues from politicized aspects; for example, the prospective of membership. This is reminiscent of similar arguments made in the case of CEE relations with the EU in the early 1990s following the development of early Association Agreements (Dangerfield 2000).

435 Importantly for the EaP states and the pro-enlargement Member States, the EaP allows potential Member States in the east to be separated from the "neighbours of Europe' in the south (Lobjakas 2008). It also represents a modest amount of progress in the potential depth and quality of relationship with the Union that the EaP countries can aspire to. Moreover, once they have met particular objectives, a fresh set of short440 term goals can be set - and thus, little by little, the quality of relations with the EU should improve. Ultimately, in the view of many interviewees, the EaP's 'offer' to the eastern ENP states was the best that could have been agreed at that particular point in time, in 2008 and 2009, given the divisions between the EU's Member States on any future enlargement beyond that to the Western Balkans (but not Turkey, which

445 remains controversial despite its candidate status). Indeed without the Russian intervention in Georgia in 2008, in the opinion of one Commission official, the Eastern Partnership might have amounted to rather less in the way of substance. ${ }^{14}$

\section{Poland's Influence on the Eastern Partnership}

Building on the previous two sections this third section examines how successful Poland has been in 'uploading' its long-held national policy preferences for relations with eastern Europe onto the common EU agenda, and in doing so it attempts an assessment of Poland's influence on the policy area during the first phase of the EaP's 455 development. The authors have chosen to investigate Poland's attempts to influence this particular policy area since the Polish government made it explicitly clear both before and after EU accession in 2004 that it aimed to make its mark in the EU in this

\footnotetext{
${ }^{14}$ Interview 41, European Commission DG External Relations, Brussels, 11 December 2009.
} 
domain. Thus, the intensity with which its policy preference in this area is held, is very high - a necessary although not sufficient condition for influence. Of course,

460 Poland has other policy priorities in the EU, such as the budget or the Common Agricultural Policy, but it has never claimed that it wished to reshape either of these radically. Thus the choice of relations with the eastern neighbours is highly appropriate for this study.

Proceeding with our analysis, we return to the factors which can be used to assess 465 the capacity of a Member State on a given policy area that were proposed by the authors in 2010 (Copsey \& Pomorska 2010). Table 1 (below) gives a summary qualitative indication in the right hand column of whether Polish performance improved for a given variable after the election of the Civic Platform-led coalition government in October 2007.

INSERT TABLE 1 HERE

(see end of article for table)

The six factors set out in Table 1 should be taken into consideration in addition to

475 the two fixed variables that determine the potential influence of a given Member State: population and total Gross Domestic Product (GDP) (Copsey \& Pomorska 2010). Even these fixed variables are not completely set in stone, after all the population of the Member States relative to one another does shift over time: Germany became about a third larger than France, the UK and Italy after the 480 extraordinary one-off event of reunification in 1990 and the higher birth rate in the UK and France relative to Germany and Italy may again slightly tilt the balance over the next quarter century - or not. The relative GDP of Member States also varies a little over time too. This may occur very gradually as a result of structural improvements in economic performance, and much more rapidly as a result of 485 exchange rate fluctuations - though this is no longer the case, of course, between euro area Member States. Historically, the UK improved its performance significantly from the mid-1980s to the mid-2000s vis-à-vis the other large European economies and moved from being the poorest large Member State to more or less parity with the others. Albeit with some interruption as a result of the economic crisis of 2007-09,

490 the newer Member States have increased their GDP relative to the other EU countries sharply since 2004 through higher growth and appreciating currencies. Nonetheless, the key point for these variables that could be said to determine potential influence in the EU is that they shift far too slowly for any particular government to be able to affect a radical change during its term of office. Thus, for the purposes of this study,

495 we concentrate solely on Polish performance for each of the explanatory factors set out in Table 1.

We begin with the variables where we judge Polish performance to be most improved and summarize why our judgement was unaltered for the other factors afterwards.

\section{Skill at Alliance Building}

It is the field of alliance building in the European Union where Polish performance could be said to have improved most strongly between 2007 and 2009. The election of the Donald Tusk's administration in 2007 was welcomed in Brussels with relief and to paraphrase one cabinet official in the European Commission, the Brussels 
community was anxious to welcome the new government. ${ }^{15}$ Tusk and his foreign minister Radek Sikorski were viewed so positively because their predecessors, Prime Minister Jarosław Kaczyński and foreign minister Anna Fotyga had been unpopular,

510 which was reflected well in the European media. Parallels were drawn by the official with the election of Sarkozy after Chirac, who became increasingly undiplomatic in his second term of office (2002-2007), particularly at the time of the Iraq war, when he remarked that the then pre-accession central European states had missed 'a good opportunity to keep quiet' and were 'not well brought up'. 16

515 The evaluation of officials both from the Commission and the Council Secretariat was that from 2007 the Poles learnt to compromise and be more modest in their proposals. ${ }^{17}$ The clearest example of this was in deciding to launch the EaP jointly with another Member State, rather than presenting the plan as a purely Polish initiative. On the other hand, as one official pointed out, it meant also sharing this 520 success and losing to certain extent the 'ownership' of the proposal. Still, it could be argued that one of the lessons learnt by Polish diplomats in Brussels was to accept this trade-off.

The choice of Sweden was not immediate - other Member States were solicited as potential partners for Poland, as one anonymous Lithuanian official recalled:

We were approached quite early on, Poland addressed Lithuania at the very beginning and then things cooled off ... Poland realized that Sweden was a better partner to work with because it was headed for the Presidency ... we did feel left out.

530 A similar account came from the Czech Republic, who raised the initiative within the Visegrád Group and presented its non-paper there for discussion.

Another official noted that the Polish MFA has a tactic of adopting a policy of complete silence when unsure of how to respond to a tricky matter in the hope that the problem will just go away ${ }^{18}$ - and expressed mild diplomatic frustration with this sort 535 of behaviour, which shows that perhaps the Polish administration still had some creases to iron out in its alliance-building strategy. Nonetheless, the choice of Sweden was excellent - a Member State with the reputation of being a reliable, honest broker, a solid advocate of deeper integration with the European Union for the EaP countries and of eventual Ukrainian accession to the European Union, as well as an altruist in 540 foreign affairs. Generally, involving Swedish partners was considered as a smart move on the part of Polish diplomats and, in particular, of Polish Foreign Minister Radek Sikorski. Swedes had a particular impact on the later, more practical shaping of the Eastern Partnership work programmes, and also discouraged the Poles from attempting a more ambitious project. The presentation of the initiative also improved 545 after the Swedes joined, with one Commission official claiming that Sweden 'translated the EaP into the language of the EU'. In the words of one Swedish official,

In the very beginning, Poland suggested an initiative that was very far from what we have now. Initially, they wanted to organize an initiative that would be parallel to and separate from the ENP.

\footnotetext{
${ }^{15}$ Interview 31, European Commission, Brussels, 20 February 2009.

${ }^{16}$ See CNN, 13 February 2003, 'Chirac Lashes Out at New Europe', available at: http://www.cnn.com/2003/WORLD/europe/02/18/sprj.irq.chirac/, last accessed 8 July 2013.

${ }^{17}$ Interview 38, European Council, Brussels, 9 December 2009 \& Interview 40, European Commission DG External Relations, 10 December 2009.

${ }^{18}$ Other officials have noted that the Polish Foreign Ministry has a tendency to ignore letters that it does not know how to respond to. Interview 23, UK Embassy, 16 May 2008.
} 
The Polish government wanted to create something else, something new. At that time, Sweden did not support the idea very much because we are committed to ENP in its current form. ${ }^{19}$

The Swedish official thus indicated that the Polish idea for a new initiative towards the East evolved over time and shifted from a highly ambitious project, the details of which were never fleshed out because it never left the drawing board, to being a more pragmatic proposal that could be launched together with the Swedes. In addition to this 'critical friend' feedback offered in the early stages of the EaP, the Swedes crucially provided extensive support at a much later stage in the evolution of the EaP, this time for the Czech Presidency in steering the EaP through the Council 560 working groups. In the words of one anonymous official from the Commission, the Czechs were 'incapable of bringing the ship safely to port without the Swedes' ${ }^{20}$ For the Poles too, being able to draw upon the Swedish reputation, their longer experience as a Member State and all the intricate detail about how to manage a project through the structures of the European institutions was invaluable. Of course, this suited the 565 Swedes too, because by partnering with a new Member State, like Poland or Lithuania, with a reputation for being 'vociferous, more active and even provocative', helped Sweden to be 'perceived as a more moderate partner' since 'with other countries more extreme than ourselves we gain a good bargaining position'. ${ }^{21}$

Another factor that signals Poland's closer attention to alliance building was the greatly improved relationship with Germany following the Parliamentary election of 2007. The efforts of both Donald Tusk and Radek Sikorski to take a softer line on the 'politics of the past', for example, on the Centre Against Expulsions under the auspices of a planned German Historical Museum Institute, no doubt contributed to this. The previous Polish Law and Justice-led coalition government as well as Polish 575 President Lech Kaczyński had often been undiplomatic about Germany, as has been documented elsewhere (Copsey \& Pomorska 2010). The importance of the alliance with Germany is best summarized in the words of an anonymous Commission official: 'It is important to recognize that Poland's role in the EU is highly conditioned by its relationship with Germany which in turn is conditioned by 580 Germany's relationship with Russia'.22

Relations with France and the UK were 'surprisingly good', in the opinion of one experienced official. ${ }^{23}$ Nonetheless, the relations with the southern Member States, especially with Spain, remained slightly strained (for example, regarding the readmission procedure with Georgia). Poland also did not introduce the initiative as a

585 Visegrád idea and for some time had a difficult relationship with the Czechs, who felt excluded (in spite of the fact that they also presented a non-paper which was discussed between the Visegrád partners). ${ }^{24}$

Finally, effective coalition building in the EU requires excellent coordination between different issues and, therefore, also between different institutional bodies, 590 such as the Council Working Groups. In the complex Brussels game, where negotiations are based on package deals, having an overview of the whole agenda is essential. It was claimed by a Commission official that Poland still needed to master the skill of 'playing on a few pianos at the same time'. ${ }^{25}$ Poland's weakness in this

\footnotetext{
${ }^{19}$ Interview 33, Swedish COEST, Brussels, 10 November 2009.

${ }^{20}$ Interview 40, European Commission DG External Relations, Brussels, 10 December 2009.

${ }^{21}$ Interview 33, Swedish COEST, Brussels, 10 November 2009.

${ }^{22}$ Interview 41, European Commission DG External Relations, Brussels, 11 December 2009.

${ }^{23}$ Interview 54, European Commission DG External Relations, Brussels, 23 November 2009.

${ }^{24}$ Interview 32, Czech COEST, Brussels, 26 October 2009.

${ }^{25}$ Interview 40, European Commission DG External Relations, Brussels, 10 December 2009.
} 
area is linked to another assessment criteria in our analysis - administrative capacity (see pp. 17-18). page numbers to be updated for final publication

\section{Persuasive Advocacy}

600

During the course of 2007 and 2008, Poland's arguments for an upgrading of the institutional framework for relations with the Union's eastern neighbours certainly became more persuasive. Three reasons can be identified to explain this improvement to Poland's skills-set as an advocate in foreign affairs.

First, the Polish government and administration's image in Brussels, as well as its reputation as a credible and reliable partner was boosted over time by a change of 605 government following the elections of 2007. The new Civic Platform-led coalition abandoned the rhetoric of euroscepticism (Cianciara 2008) and, following an embarrassing tug-of-war between President Kaczyński and Prime Minister Tusk over who represented Poland at summits, which culminated in two separate delegations arriving at the Council in Brussels on 15 October 2008 necessitating a game of

610 musical chairs in the Council chamber to allow the President to take a seat next to the Prime Minister ${ }^{26}$, the primary responsibility for foreign affairs was assumed by the Government and foreign minister. In May 2009, the Polish Constitutional Court ruled that the President may himself decide whether to participate in the European Council, but it is the Government who decides what the Polish position will be (Gazeta Prawna 615 2009). The Court also ruled that the President did not have the prerogative to conduct an independent foreign policy or to direct relations with international organisations.

Second, the Polish government became a little more measured in its advocacy of Ukraine and the eastern neighbours' integration potential. Calls for a membership perspective to be extended to the eastern partnership countries were dropped, as one

620 Commission official noted, 'both Poland and Sweden were circumspect at COEST',27 not pushing too far or too fast. It seemed that the Poles had learnt an important lesson concerning the value of 'constructive ambiguity' for a policy area where there are considerable differences of opinion between the Member States. This strategic behaviour does not imply any change in the crucial interest of bringing Ukraine into

625 the EU, but rather the adoption of different tactics. However, there remained some work for Polish officials to undertake in finessing their skills at playing the Brussels game, and they remained, in the words of the same official, 'rather rough around the edges ... too vocal in pushing the national interest' ${ }^{28}$

A similar, moderate strategy was used when the Poles approached the

630 Commission. There were consultations between Polish officials from the MFA in Warsaw and the Commission in March and April 2008. As reported in the interviews, what surprised some officials in Brussels was that the Poles repeated persistently that the initiative was not anti-Russian and that it had nothing to do with the membership perspective for the countries involved. However, some of Poland's partners in the 635 Union thought that the Polish government was protesting too much - after years of presenting itself as a steely, sceptical cold warrior vis-à-vis Russia and emphasizing the geopolitical imperative of preventing Russian expansion, the Polish government

\footnotetext{
${ }^{26}$ See, 'Polish President Wins EU Summit Bunfight', available at: http://euobserver.com/9/26948, last accessed 5 July 2013.

${ }^{27}$ COEST is a geographical Council Working Group dealing with Eastern Europe and Central Asia.

${ }^{28}$ Interview 40, European Commission DG External Relations, Brussels, 10 December 2009.
} 
lacked credibility in arguing that there was nothing anti-Russian in the EaP (whether the statement was objectively accurate or otherwise).

640 Third, the credibility of the Polish sceptical position on the role played by Russia within the political sphere occupied by EaP states was much enhanced by the Russian intervention in Georgia in 2008. Russia's actions did not bring about a great shift in the attitude of the Russia-friendly Member States, such as Germany, France and Italy. After all, the Georgian government was not judged to have acted entirely innocently 645 in the run-up to the conflict either. However, the war in Georgia cast a very favourable light on a case that had been advocated by Poland for a number of years: that the countries between Russia and the European Union needed an improved relationship with the EU, partly for their own security and partly for the security of the EU.

650 Thus, it was not so much that Poland's underlying arguments in favour of an improved institutional framework for relations with the Eastern neighbours had shifted radically, beyond abandoning advocacy of a membership perspective in the near future, rather an exogenous event provided a much-needed boost to the credibility of a long-held Polish position, which also raised relations with the Eastern

655 neighbours up the Commission's agenda.

\section{Receptiveness of Other Member States}

The third area in which there had been improvement in the capacity of Poland to 660 exercise influence on the area of relations with the eastern neighbours concerns the receptiveness of other Member States to Polish ideas about improving the relationship between the EU and its eastern neighbours. Three factors were of crucial importance here: (1) the war in Georgia in 2008, which came only a few weeks after the original proposal for an Eastern Partnership; (2) the launch of the Union for the Mediterranean

665 during the French Presidency of 2008; and (3) the election of Nicholas Sarkozy as President of France in 2007.

Before turning to these key points, it is worth re-iterating that in headline terms, the positions of the Member States on the finalité politique of Ukraine's European integration remained much the same in 2010 as previously, with the usual splits

670 between the central European 2004 accession Member States (plus the UK and Sweden) which are in favour of accession (particularly for Ukraine) and the Club Med countries (Spain, Italy, France, Portugal and Greece) plus Austria and Belgium which are firmly against. The other Member States tend to fall somewhere in the middle of these two positions, erring more on the side of strong scepticism about accession, 675 however distant. For this reason, the membership question is never discussed in Brussels - to the frustration of the Ukrainians especially.

Nonetheless, the positions of some Member States shifted in 2008 towards being a little more accommodating towards the Eastern neighbours' desire to integrate with the EU. At the very least, the Member States recognize that the EU needs to have a 680 stronger presence in the region as an initiator of multi-lateral co-operation between the six former Soviet Republics that make up the region (excluding Russia) - which is, of course, what the Eastern Partnership seeks to do. This was certainly the result of the war in Georgia in August 2008 (as confirmed by a number of interviewed 
officials $^{29}$; see also Ochman 2010, pp. 4-5 for a German position), which underlined the costs of non-engagement or limited engagement in the region. While the interviewee at the Secretariat General of the Council claimed that the EaP initiative was warmly welcomed from the very beginning, one anonymous senior official described the progress of the EaP idea through the Commission from the initial Polish-Swedish proposal as something more complex:

690

Well, because it came from the NMS [new member state] there was automatic sympathy, but the general attitude to the proposal was rather negative. Having yet more initiatives did not seem credible to the Commission. We had a lot already. So we were sceptical about the added-value and the multi-lateral dimension. We saw no need for a new initiative [...] What changed all this was the war in Georgia. The Emergency European Council sent a request to the Commission to speed up and bring forward proposals from spring 2009 to autumn/winter 2008. Some member states felt that we couldn't stand up to Russia directly but we could foster cooperation in the region [...] we needed a positive signal to the Georgians [...] At that point in the Commission we knew that a more ambitious proposal would fly. So it was a success for Polish diplomacy - but they were pushing at an open door. Support came from the very top of the Commission. From Barroso and Catherine Day, who convened a meeting of the Director-Generals and told them to fast-track the proposal. $^{30}$

This account of events was confirmed by other interviewees from the 705 Commission. Other officials stressed that without the crisis in Georgia the Polish proposal would either have been 'left on the shelf' or have moved very slowly, due to its lukewarm reception from senior officials at the Commission's Directorate General for External Relations (DG Relex).

It was not only the war in Georgia that prompted a shift on the part of those 710 Member States traditionally hostile towards upgrading the EU's relations with its eastern neighbours, it also helped that the Union for the Mediterranean for relations with the EU's southern neighbours had already been agreed - acting as a quid pro quo for the Eastern Partnership. As one Spanish official noted, the 'Eastern Partnership does not fall in the sphere of our natural interests ${ }^{31}$ (which are the Mediterranean and

715 Latin America), but the Spanish were not actively opposed to the policy set out in the Eastern Partnership since it has been agreed by all the Member States. In other words, once a policy idea has been adopted by consensus, everyone has to back it, or at least not actively oppose its continuation. Moving relations with the eastern neighbours away from the political towards the technical was an important part of the Polish 720 strategy; as an anonymous official underlined, the Poles aimed to 'discourage our partners from imposing a political perspective on everything, ${ }^{32}$ As a Polish official admitted, the aim was 'not to make a revolution' but rather deepen existing relations.

A final illustration of how the receptiveness of the other Member States towards Poland's ideas for relations with the eastern neighbours altered to the advantage of the 725 Poles, can be found in the case of France. France is not only a large, rich and founding Member State of the Union but it can also perhaps be described as a 'veto player' on EU external policy and, certainly, on enlargement issues. The French position has undergone a considerable evolution since the election of President Nicholas Sarkozy in 2007 and France could now be cautiously described as being in favour of some

\footnotetext{
${ }^{29}$ Interview 40, European Commission DG External Relations, Brussels, 10 December 2009; Interview 41, European Commission DG External Relations, Brussels, 11 December 2009; Interview 38, European Council, Brussels, 9 December 2009.

${ }^{30}$ Interview 41, European Commission DG External Relations, Brussels, 11 December 2009.

${ }^{31}$ Interview 45, Spanish COEST, Brussels, 27 November 2009.

${ }^{32}$ Interview 34, Polish COEST, Brussels, 27 October 2009.
} 
730 European integration for the countries of the East, in contrast to the Chirac Presidency (1995-2007) when France had in the words of one French diplomat 'an extremely restrictive approach to Ukraine', ${ }^{33}$ a position which hardened following the defeat of the European Constitutional Treaty in a French referendum in 2006.

France is now a supporter of the Eastern Partnership and recognizes that relations

735 with the eastern neighbours need to be put on a firmer footing through the negotiation of Association Agreements. However, there remain in the words of a French diplomat two 'red lines' ${ }^{34}$ for France's attitude towards Ukraine's European integration. First, 'all debate on enlargement must be excluded from discussions with Ukraine'. ${ }^{35}$ Second, the balance must be maintained between per capita spending in the Eastern 740 neighbourhood and spending in the Southern neighbourhood - that is the South will receive rather more than the East by virtue of its higher population. An anonymous Commission official also reported that France has argued that for every extra cent spent in the East, two cents more must be spent in the South to maintain the balance. ${ }^{36}$

\section{Administrative Capacity/Experience}

Our assessment of administrative capacity of Poland remains more critical. The evidence points at remaining weaknesses with regard to initiating, co-ordinating and following-up the policies in Brussels. One anonymous official, while admitting there

750 was a lot of improvement in this area, for example in the quality of response to the Commission's proposals from the Polish side, said there remained 'room for improvement'. The timing of Polish initiatives was not always appropriate - after all, it was sheer chance that the war in Georgia broke out not long after the Poles and Swedes had put forward their proposals. Internal tensions over external relations

755 competences and the involvement of the Office of the Committee for European Integration (UKIE) were another issue that has yet to be resolved in order to achieve more effective policy co-ordination. A couple of other officials questioned the effectiveness of the new division of labour and co-operation between the old 'core' MFA and UKIE since the incorporation of the latter into the former.

760 Some officials from the Commission thought Poland had 'not existed in Brussels with regard to the Eastern Partnership' ${ }^{37}$, after it had been 'rubber-stamped' by the European Council in June 2008. They had the impression that Warsaw was celebrating this success without actively engaging in shaping the future of the policy in detail - and thus were it not for the war in Georgia, the initiative would have trailed

765 off into nothing, as is often the case with these kinds of new ideas for policies. More experienced Member States follow-up the shaping of their proposals, albeit discreetly. One official claimed that Warsaw did not have enough people who understood how the European Commission really worked and what instruments could be used now to 'push things forward'. Those who had previously worked in the Polish Permanent

770 Representation either left to work in the institutions or, after returning to the MFA in Warsaw, were quickly rotated (for example, to Vienna, Washington or Madrid). It

\footnotetext{
${ }^{33}$ Interview 37, ex French COEST, Brussels, 9 December 2009.

${ }^{34}$ Interview 37, ex French COEST, Brussels, 9 December 2009

${ }^{35}$ Interview 37, ex French COEST, Brussels, 9 December 2009

${ }^{36}$ Interview 40, European Commission DG External Relations, Brussels, 10 December 2009.

${ }^{37}$ Interview 55, European Commission DG External Relations, Brussels, 23 November 2009.
} 
seemed to one official in the Commission that in Poland there is still the perception of 'us in Warsaw' and 'them in Brussels'. 38

In consequence, many proposals are prepared for internal political audiences, rather than to bring real change in the EU. As an example of such an initiative, which had many positive aspects, but was not properly introduced, was the Polish idea of making the choice of the EU High Representative for the CFSP more transparent. One anonymous Warsaw-based Polish official believed that had Poland consulted more closely with Brussels-based Polish officials, the idea could have been presented earlier, for example, through a think-tank or a foundation and not by the Polish MFA itself.

The disconnect between Warsaw and Brussels was highlighted by one senior and very experienced Polish official, who argued that 'Poland has trouble getting its people to cooperate'. ${ }^{39}$ In particular, there was a lack of cooperation between Poles working in the European institutions and for the Polish government, either in Brussels in the Permanent Representation or Warsaw. The official went on to state that 'cooperation between those who work on Europe both in Warsaw and Brussels is both crucial and lacking, ${ }^{40}$ Successful Member States build networks of officials and 'there are not enough Poles in senior positions and not enough in the cabinets ...

790 Getting Poles into the right jobs is a problem for the Perm Rep and for Warsaw ... the Perm Rep is just not a good intermediary for Poles seeking employment" ${ }^{41}$ A final point strongly expressed was that Poles working for European institutions outside the office of the Polish Commissioner are seen as 'not one of us'. The official also revealed that, following the best practice of older Member States, the Polish 795 government had convened a meeting in Warsaw of senior Poles working for the European institutions in Brussels in an attempt to build a network and to discuss the Polish government's European agenda for the coming year with them. However, when the officials working for European institutions attempted to comment on the Polish government proposals they were told to sit down and keep their opinions to 800 themselves since they 'had left the Polish service' and were 'working for foreigners' ${ }^{42}$ This would appear to be clear evidence that it takes a very long time for new Member States to shift their mindset towards feeling that they are full members of the European Union - and to have the confidence to realise that Polish officials working at a senior level in the EU represents a success and are a valuable asset for the Polish civil service, rather than a betrayal of national loyalties.

\section{Conclusions}

The main argument in this article is that in the opinion of Poland's partners in the 810 Permanent Representations of the other Member States and officials in Brussels, the launch of the Eastern Partnership was to a considerable extent the fruit of persistent Polish efforts in this policy area. The article also demonstrates that the negotiations which led to the launch of the Eastern Partnership showed that by mid-2008 Poland had learnt important lessons about how to adapt, modify and adjust national policy 815 preferences in such a way that they could be rebranded as 'European' preferences and

\footnotetext{
${ }^{38}$ Interview 31, European Commission, Brussels, 20 February 2009.

${ }^{39}$ Interview 31, European Commission, Brussels, 20 February 2009.

${ }^{40}$ Interview 31, European Commission, Brussels, 20 February 2009.

${ }^{41}$ Interview 31, European Commission, Brussels, 20 February 2009.

${ }^{42}$ Interview 31, European Commission, Brussels, 20 February 2009.
} 
not simply 'Polish' preferences. Nonetheless, Poland's performance was not entirely flawless and there were still shortcomings on the Polish side, especially in coordination between Brussels and Warsaw as well as with the follow-up process.

We argue that the Polish government elected in 2007 appeared to have learnt a number of key lessons for the conduct of negotiations with its partners in the EU, as follows. First, the Poles learned to tone down their rhetoric and to put forward modest proposals that are harder for the other Member States to oppose without seeming unreasonable. Secondly, the Poles had learned the value of what one official termed 'constructive ambiguity'. This consists of recognizing that the best means of advancing one's goals in a policy domain where there is a lack of collective enthusiasm or agreement about what the eventual outcome should be is quite simply to be studiously vague about where the policy is heading. Given the clear lack of consensus between the Member States about what kind of relationship (for example, accession to the EU, an EEA or European Free Trade Association (EFTA) style 830 partnership, a 'privileged partnership') they want with their eastern neighbours, such a policy of 'constructive ambiguity' is highly appropriate. Forging a consensus based on this guiding principle could in essence be said to consist of three elements, which are as follows. First, set concrete, minimalistic targets for the given policy domain that all the Member States can agree on. Second, depoliticize the overall policy issue 835 by making the achievement of the modest goals set a purely bureaucratic issue that can be managed by the European Commission. Third, set a relatively short timeframe for the completion of the modest set of targets and once these objectives have been met, put in place another modest set of targets. This strategy represents a rediscovery with a recalibration of the tried-and-tested, incremental 'Monnet method' of European 840 integration that focused on the logic of small steps that are at least moving towards the goal of integration, however slowly.

Poland's ability to exercise influence in the European Union during its first years of membership remained constrained by its weakness in administrative capacity, the primary factor highlighted in our earlier work (Copsey \& Pomorska 2010). Only part 845 of this can be still explained by a lack of experience, but it also seemed that the kind of structures that would oblige Polish officials to work constructively together were not yet fully in place. Major problems in this area were the lack of effective coordination, and continued weaknesses in 'lobbying' the EU institutions, especially in the phase after the policy had been accepted by the Council. Re-rotating the officials

850 returning to Warsaw from Brussels and weak systems of knowledge transfer (also of the lessons learned at the individual level) for those leaving to the EU institutions are one of the obstacles to improvement in the administration capacities. More systemised research is needed in this field to evaluate the present institutional design for domestic policy coordination.

855 In the field of alliance building, Poland's performance was dramatically improved by its choice of Sweden as its primary ally for the launch of the Eastern Partnership. This meant that the Poles could draw not only on Sweden's reputation as an 'honest broker', but also its experience of working in the European institutions. However, as this initiative came from the highest political level, it remains to be seen whether the 860 lesson has become institutionalized and whether we will witness other successful alliances in the future, at all levels of decision-making. Poland is only just beginning to cultivate allies over a longer term period and it continues to experience difficulties in forging alliances with potentially key partners, such as Germany, and even at times with the other Visegrád states, where Poland often continues to seek a leadership role 865 to the vexation of the others. In the words of one Visegrád country official, 'other 
Member States might not appreciate it when one of them is trying to put on political weight' ${ }^{43}$ The other allies that Poland had sought for the Eastern Partnership initially were also disappointed to be cast aside without any communication once the Swedish choice had been made. Whilst much alliance-forming in the European Union is purely ad hoc on an issue-by-issue basis following the British model, those Member States such as France and Germany that seek to make their mark tend to consider alliance building over the very long term. Poland has to decide for itself which model to follow.

Before concluding this article, it is worth making a final observation for future research on the nature of the capacity of Member States to exercise power and influence in the European Union. Future research needs to go beyond Lukes' second dimension of power (persuasion) and develop a framework for investigating the third dimension of power (shaping norms and values - i.e. the parameters within which debate is framed). ${ }^{44}$ Although the EU has always, to an extent, been driven by norms 880 and values as well as economic imperatives (in the beginning, preventing future European wars and the consolidating democracy in Europe), since at least the Helsinki Final Act of 1975, European governments have become steadily committed more to the protection of ever more broadly defined universal 'human rights'. Protection of human rights is often invoked as a means of coercing governments into making decisions that they - and sometimes their electorates - would otherwise have been opposed to. ${ }^{45}$ It is not unreasonable to suggest that Member States that seek true influence in the Union over the long term should set their sights on redefining what is normal. In that way, they will be able to shape the future direction of the Union without the Member States or the institutions realising. This is perhaps is how power

890 is most effectively exercised in the Union. Empirical studies that map this process over the longer term, and in particular that chart the newer Member States' efforts to participate in shaping norms, would be a welcome addition to the literature on power and influence.

In sum, the combined success of getting Eastern Partnership on the Council agenda at the right moment, finding consensus between the Member States and winning the backing of the Commission was probably the greatest achievement of Polish diplomacy within the EU during its first five years of membership. Our study has shown that there was an improvement in Polish performance and the overall country's influence increased after the election of the Civic Platform-led coalition

900 government in 2007. It remains to be seen whether this successful experience has served as a positive lesson learnt and become institutionalized in terms of how Poland operates at the European level. Certainly, Poland has sought to keep relations with the EU's Eastern neighbours high on the Union's political agenda in the subsequent years following the first phase of EaP, but the direct influence of Poland on shaping the 905 future policy remains to be analysed.

\section{Aston University \& Maastricht University}

\footnotetext{
${ }^{43}$ Interview 32, Czech COEST, Brussels, 26 October 2009.

${ }^{44} \mathrm{We}$ are grateful to Darina Malova for this point.

${ }^{45}$ A key example of this is the way that the British government appeared in 2010 to be obliged to give prisoners serving sentences the right to vote in elections.
} 


\section{References}

Bechev, D. \& Nicolaidis, K. (2010) 'From Policy to Polity: Can the EU's Special Relations with its 'Neighbourhood' be Decentred?', Journal of Common Market Studies, 48, 3, pp. 475-50.

Boonstra, J. \& Shapovalova, N. (2010) 'The EU's Eastern Partnership: one year backwards', FRIDE Working Paper, No. 99.

Bulmer, S. \& Lequesne, C. (2002) The Member States of the European Union (Oxford, Oxford University Press).

Buras, P. \& Pomorska, K. (2006) 'Poland the European Neighbourhood Policy'. Foreign Policy in Dialogue, 6, 19, pp. 34-43.

Cianciara, A. (2008) 'Eastern Partnership' - opening a new chapter of Polish Eastern policy and the European Neighbourhood Policy?, Analyses and Opinions, 4, (Warsaw, Polish Institute of Public Affairs).

Cimoszewicz, W. (2004) 'Europe Enlarged but Open', Statement at the OECD Council, Paris, 22 April.

Copsey, N. \& Haughton, T. (2009) 'The Choices for Europe? National Preference Formation in Old and New Member States'. Journal of Common Market Studies, 47, 2, pp. 263-286.

Copsey, N. \& Pomorska, K. (2010) 'Poland's Power and Influence in the European Union: the Case of its Eastern Policy', Comparative European Politics, 8, 3, pp. 304-326.

Council of the EU (2003) 'European Security Strategy: A Secure Europe in a Better World'. Brussels, 12 December 2003.

Council of the EU (2008) 'Presidency Conclusions of the Brussels European Council', 19 \& 20 June 2008, 11018/08.

Council of the EU (2009) 'Joint Declaration of the Prague Eastern Partnership Summit', 7 May 2009, 8435/09.

940 Dangerfield, M. (2000) Subregional Economic Cooperation in Central Europe: The Political Economy of CEFTA (Cheltenham, Edward Elgar).

Dangerfield, M. (2010) The Contribution of the Visegrad Group to the European Union's 'Eastern Partnership'; Rhetoric or Reality?, Europe-Asia Studies, Vol. 61 No. 10, 1735-1755.

945 Dannreuther. R. (2004) (ed.) European Union Foreign and Security Policy. Towards a Neighbourhood Strategy (London: Routledge).

Emerson, M. (2004) 'European Neighbourhood Policy: Strategy or Placebo?', CEPS Working Document N 215, Centre for European Policy Studies, Brussels.

Emerson, M., Noutcheva, G. and Popescu, N. (2007) 'European Neighbourhood Policy Two Years on: Time Indeed for an 'ENP Plus'. CEPS Policy Brief No. 126, Centre for European Policy Studies, Brussels.

European Commission (2003) 'Wider Europe - Neighbourhood: A New Framework for Relations with our Eastern and Southern Neighbours, Communication from the Commission to the Council and the European Parliament'. $\operatorname{COM}(2003) 104$ final.

European Commission (2004) 'European Neighbourhood Policy Strategy Paper' Brussels, 15.05.2004, COM (2004) 373 Final.

European Commission (2008) 'Communication from the European Commission to the European Parliament and the Council', Eastern Partnership, 3 December 2008, 823 Final. 
Gazeta Prawna (2009) 'TK w sprawie sporu kompetencyjnego: prezydent sam decyduje o udziale w szczytach UE, rzad ustala stanowisko', available at: http://prawo.gazetaprawna.pl/artykuly/319182,tk_ws_sporu_kompetencyjnego prezydent_sam_decyduje_o_udziale_w_szczytach_ue_rzad_ustala_stanowis ko.html, accessed on 10 January 2010.

Kelley, J. (2006) 'New Wine in Old Wineskins: Promoting Political Reforms through the New European Neighbourhood Policy', Journal of Common Market Studies, 44, 1, pp. 29-55.

Kupiecki, R. and Szczepanik, K. (1995) Polityka zagraniczna Polski, 1918-1994 (Warsaw, Scholar).

Landaburu, E. (2006) 'From Neighbourhood to Integration Policy: Are there Concrete Alternatives to Enlargement?' CEPS Policy Brief No. 95.

Lobjakas, A. (2008) 'EU: New Initiative Suggests East is Edging Out South in Neighbourhood Tussle', RFE/RL Newsline, 28 May 2008.

975 Longhurst, K. \& Zaborowski, M. (2007) A New Atlanticist: Poland's Foreign and Security Policy Priorities (Oxford, Blackwell/Chatham House).

Lukes, S. (2005) Power: A Radical View (Basingstoke, Palgrave Macmillan).

Meller, S. (2006) 'Government Information on Polish Foreign Policy in 2006: Presented at the Session of the Sejm'. Warsaw, 15 February 2006.

980 MFA (2003) 'Non-Paper with Polish proposals concerning policy towards the new Eastern neighbours after EU enlargement', (Warsaw, Ministry of Foreign Affairs of the Republic of Poland).

MFA (2006) 'European Neighbourhood Policy - Eastern Dimension and EU-Ukraine Relations. Food for Thought/ Polish Proposals' (Warsaw, inistry of Foreign Affairs of the Republic of Poland).

Moravscik, A. (1998) The Choice for Europe: Social Purpose and State Power from Messina to Maastricht (Ithaca, Cornell University Press).

Ochman, C. (2010) Przyszlosc Partnerstwa Wschodniego z niemieckiej perspektywy, Biuletyn niemiecki, 6 (Warsaw, Centre For International Relations).

990 Olechowski, A. (1994) 'Partnerstwo dla Transformacji', in M. Bankowicz, L. Parczewska \& D. Styrna (eds) W Stronę Nowego Partnerstwa: PolskoRosyjska Konferencja (Krakow, Cracovia).

Sasse, G. (2010) 'The ENP and the EU's Eastern Neighbours: Ukraine and Moldova as Test Cases', in R.G. Whitman, \& S. Wolff (eds), The European Neighbourhood Policy in Perspective: Context, Implementation and Impact (Basingstoke, Palgrave Macmillan).

Schimmelfennig, F. \& Scholz, H. (2008) 'EU Democracy Promotion in the European Neighbourhood', European Union Politics, 9, 2, pp. 187-215.

Smith, K. (2005) 'The Outsiders: the European Neighbourhood Policy', International Affairs, 81, 4, pp. 757-73.

Tallberg, J. (2008) 'Bargaining Power in the European Council'. Journal of Common Market Studies, 46, 3, pp. 685-708.

Wallace, H., Wallace, W. \& Pollack, M.A. (2005) Policy-Making in the European Union (Oxford, OUP).

1005 Weber, K., Smith, M. E. \& Baun, M. (eds) (2007) Governing Europe's Neighbourhood: Partners or Periphery? (Manchester, Manchester University Press).

Whitman, R. \& Wolff, S. (2010a) The European Neighbourhood Policy in Perspective: Context, Implementation and Impact (Basingstoke, Palgrave Macmillan). 
Whitman, R. \& Wolff, S. (2010b) 'Much Ado About Nothing? The European Neighbourhood Policy in Context', in R. Whitman, \& S. Wolff (eds), The European Neighbourhood Policy in Perspective: Context, Implementation and Impact (Basingstoke, Palgrave Macmillan).

1015

1020

1025

1030

1035

1040

1045

1050

1055 
TABLE 1

POLAND'S VARIABLE POLITICAL POWER AND INFLUENCE IN THE EUROPEAN UNION: THE CASE OF ITS EASTERN POLICY

\begin{tabular}{ll}
\hline Variable & Qualitative Improvement since 2007 \\
\hline Intensity of Policy Preference & No change \\
Skill at Alliance Building & Improved \\
Administrative Capacity & No change \\
Persuasive Advocacy & Improved \\
Receptiveness of other Member States & Slightly improved \\
Domestic Political Strength & No change \\
\hline
\end{tabular}

Source: Wallace (2005) and authors' own data. 